\title{
SIKAP KERJA PRAMUSAJI PADA MATA PELAJARAN TATA HIDANG "MELAYANI LAYANAN MAKANAN DAN MINUMAN" SISWA KELAS XI SMKN 3 CIMAHI
}

\author{
Zulnisa Addawiyah', Atat Siti Nurani², Yulia Rahmawati ${ }^{3}$ \\ Program Studi Pendidikan Tata Boga, Departemen Pendidikan Kesejahteraan \\ Keluarga, Fakultas Pendidikan Teknologi dan Kejuruan, Universitas Pendididkan \\ Indonesia
}

zaddawiyah@gmail.com

\begin{abstract}
Abstrak: Kurikulum SMK tahun 2013 berhubungan dengan bentuk perilaku dan sikap, dalam struktur kurikulum SMK pada mata pelajaran Tata Hidang kelas XI di SMK Negeri 3 Cimahi sikap kerja sangat menunjang dalam pelaksanaan kompetensi dasar Melayani Layanan Makanan dan Minuman. Tujuan penelitian ini adalah untuk mengumpulkan data bahwa siswa melaksanakan sikap kerja pada tahapan preparation, general service procedure, dan closing restaurant, sehingga peserta didik mampu mewujudkan kompetensi yang dibutuhkan. Metode penelitian yang digunakan yaitu kuantitatif dengan desain Cross-Sectional. Teknik sampling yang digunakan oleh penulis adalah Simple Random Sampling, yang berjumlah 58 siswa kelas XI Boga SMKN 3 Cimahi. Teknik pengumpulan data menggunakan instrumen angket/kuesioner. Berdasarkan hasil penelitian yakni pada indikator preparation meliputi mise en scene dan mise en place sebagian besar responden (93\%) sangat baik dan lebih dari setengahnya $(74 \%)$ baik, pada indikator general service procedure meliputi penampilan dan sequence service sebagian besar responden $(97,24 \%)$ sangat baik dan lebih dari setengahnya (80\%) baik, sedangkan pada indikator closing restaurant sebagian besar (88\%) sangat baik. Disimpulkan bahwa siswa kelas XI Boga SMKN 3 Cimahi dapat melaksanakan sikap kerja pramusaji pada mata pelajaran Tata Hidang dengan baik dan benar sesuai dengan prosedur yang terdapat pada silabus.
\end{abstract}

Kata kunci: Pramusaji, Tata Hidang, Sikap Kerja

\section{LATAR BELAKANG MASALAH}

Struktur kurikulum SMK tahun 2013 terdiri dari mata pelajaran sesuai dengan bidangnya. Mata pelajaran yang dibagi ke dalam tiga kelompok 1) Kelompok A (Wajib Nasional), 2) Kelompok B (Wajib Regional), dan 3) Kelompok C (Peminatan) salah satunya yaitu mata pelajaran Tata Hidang. Peraturan Pemerintah Nomor 17 Tahun $2010 \quad$ tentang Penyelenggaraan dan Pengelolaan Pendidikan Pasal 80 menyatakan bahwa: (1) penjurusan pada SMK, MAK, atau bentuk lain yang sederajat berbentuk bidang keahlian; (2) setiap bidang keahlian sebagaimana dimaksud pada ayat (1) dapat terdiri atas 1 (satu) atau lebih program studi keahlian; (3) setiap program studi.

Salah satu mata pelajaran keompok $\mathrm{C}$ adalah mata pelajaran tata hidang di mana mata pelajaran tersebut memiliki kompetensi dasar yang harus dipelajari oleh peserta didik kelas XI, terdapat 14 kompetensi dasar pada mata pelajaran Tata Hidang. Salah satunya yaitu terdapat pada kompetensi KD. 3.8 Mengevalusai layanan makan dan minum dan KD. 4.8 Melayani makan dan minum yang mengharuskan siswa mempunyai sikap kerja profesional dalam hal menyangkut pekerjaan dan mata pelajaran ini sebagai dasar untuk mengikuti program lapangan, sehingga diperlukannya sikap kerja untuk 
melaksanakan kompetensi dasar tersebut, dan sebagaimana yang dijelaskan oleh Yustriani, Elly L. dan Yulia Rahmawati (2016, Vol 5, No. 1) bahwa kegiatan pembelajaran dapat dinilai dari tiga aspek kemampuan diantaranya pengetahuan (kognitif), sikap (afektif), dan keterampilan (psikomotor). Berdasarkan hasil pengamatan dari penelitian tersebut, studi awal ditemukan beberapa permasalahan terkait dengan aspek kemampuan sikap mahasiswa pada proses pembelajaran praktik EO meliputi; sikap penerimaan (receiving), sikap partisipasi (responding), dan penilaian/penentuan sikap (valuing) pada praktik penyelenggaraan EO bidang boga.

Sehubungan dengan penelitian tersebut, pada penelitian ini masih ditemukannya permasalahan sikap kerja peserta didik kelas XI dalam memenuhi kompetensi dasar pada mata pelajaran Tata Hidang di SMK Negeri 3 Cimahi. Hal ini membuktikan bahwa sikap kerja berpengaruh terhadap pekerjaan yang dilakukan dan juga merupakan salah satu faktor yang menyebabkan pekerjaan terlaksana dengan efektif, efisien dan kondusif.

\section{METODE}

Penelitian ini menggunakan desain Cross-Sectional. Metode kuantitatif ini penulis gunakan untuk memperoleh data persentase serta pemecahan masalah dari Sikap Kerja Pramusaji Pada Mata Pelajaran Tata Hidang "Melayani Layanan Makanan Dan Minuman" Siswa Kelas XI SMKN 3 Cimahi.

Partisipan yang dilibatkan dalam penelitian ini adalah seluruh siswa program keahlian Jasa Boga kelas XI di SMK Negeri 3 Cimahi tahun ajaran
2018/2019 yang telah mempelajari standar kompetensi "Melayani Makanan dan Minuman" pada mata pelajaran Tata Hidang dengan jumlah populasi 136 orang. Teknik sampling yang digunakan oleh penulis dalam penelitian ini adalah Simple Random Sampling. Jumlah sampel yang dibutuhkan dalam penelitian ini menurut perhitungan di atas adalah sebanyak 58 orang atau peserta didik dan kemudian disebar secara acak/random (undian) pada 4 kelas yang ada.

Riduwan, 2012, hlm. 87 mengemukakan bahwa kriteria interpretasi skor dalam skala Likert berkaitan dengan penelitian ini, ialah sebagai berikut :

$$
\begin{aligned}
& 0 \%-20 \%=\text { Sangat Kurang } \\
& 21 \%-40 \%=\text { Kurang } \\
& 41 \%-60 \%=\text { Cukup } \\
& 61 \%-80 \%=\text { Baik } \\
& 81 \%-100 \%=\text { Sangat Baik }
\end{aligned}
$$

\section{HASIL DAN PEMBAHASAN}

Pengambilan data berkaitan dengan sikap kerja pramusaji sebagaimana dalam KI. 3: KD 3.8 Mengevalusai layanan makan dan minum dan KI.4: KD 4.8 Melayani makan dan minum pada materi pokok Pelayanan Makan dan Minum yang memiliki kriteria atau syarat-syarat seorang pramusaji, terutama dalam bersikap ketika melaksanakan pekerjaan menjadi pelaksanan tugas $F \& B$ Dept khususnya seorang pramusaji.

Berdasarkan hasil data Tabel 1 menunjukkan rata-rata persentase Kriteria Melaksanakan syarat sikap kerja pramusaji dalam Preparation meliputi Mise en Scene dan Mise en place ditinjau dari kemampuan seorang pramusaji Melaksanakan persiapan awal ruang kerja dan lingkungan dengan memiliki sikap 
teliti, tepat waktu, kecepatan, kehatihatian, bertanggung jawab, inisiatif, tepat waktu dan cermat sebesar $93 \%$, hal ini ditafsirkan bahwa sikap kerja pramusaji siswa kelas XI SMKN 3 Cimahi pada mata pelajaran Tata Hidang termasuk ke dalam kategori Sangat Baik. Hal ini dapat diartikan bahwa peserta didik dapat memahami sikap kerja pramusaji pada mata pelajaran Tata Hidang, sehingga peserta didik mampu mewujudkan kompetensi yang dibutuhkan.

Sejalan dengan hasil penelitian Maringan, dkk (2016, hlm. 145, Vol. 13, 2) mengemukakan bahwa dalam penelitiannya sikap kerja berpengaruh positif signifikan terhadap prestasi kerja karyawan, hal ini dikarenakan terdapat beberapa poin penting yang menunjang sikap kerja karyawan pada perusahaan, sehingga mampu menjadikan perusahaan tersebut semakin berkembang dengan baik.

Tabel 1

Sikap Kerja Pramusaji saat Melaksanakan

Preparation meliputi Mise en Scene

\begin{tabular}{|c|c|c|c|}
\hline No. & $\begin{array}{c}\text { Skor } \\
\text { Aktual }\end{array}$ & \% & Kriteria \\
\hline 1 & 278 & 95,86 & Sangat Baik \\
\hline 2 & 263 & 91 & Sangat Baik \\
\hline 3 & 272 & 94 & Sangat Baik \\
\hline 4 & 268 & 92 & Sangat Baik \\
\hline 5 & 275 & 95 & Sangat Baik \\
\hline 6 & 270 & 93,1 & Sangat Baik \\
\hline 7 & 268 & 92,41 & Sangat Baik \\
\hline 8 & 277 & 95,52 & Sangat Baik \\
\hline 9 & 109 & 37,59 & Kurang \\
\hline 10 & 269 & 92,76 & Sangat Baik \\
\hline 11 & 89 & 30,69 & Kurang \\
\hline $\begin{array}{c}\text { Rata- } \\
\text { rata }\end{array}$ & $\mathbf{2 4 0}$ & $\mathbf{9 3}$ & Sangat Baik \\
\hline
\end{tabular}

Berdasarkan hasil penelitian Khoiri (2017, hlm. 96-99, Vol. 1, No. 5) "Pengaruh Kualitas Kehidupan Kerja Dan Sikap Kerja Terhadap Kepuasan
Kerja Guru SMA Negeri Kecamatan Jekan Raya Kota Palangka Raya Provinsi Kalimantan Tengah" bahwa jika guru sebagai garda terdepan dalam membangun karakter manusia maka guru sebagai model di lingkungan pendidikan harus memiliki sikap yang baik dan profesional dalam menjalankan pekerjaanya.

Sejalan dengan hasil data Tabel 2 menunjukkan rata-rata persentase Kriteria Melaksanakan syarat sikap kerja pramusaji dalam Preparation: Mise en Scene dan Mise en place ditinjau dari kemampuan seorang pramusaji Melaksanakan persiapan meletakkan dan menempatkan barang sesuai dengan jenis dan ukuran dengan memiliki sikap teliti, kecepatan, kehati-hatian, bertanggung jawab, cekatan, dan kooperatif sebesar $74 \%$, hal ini ditafsirkan bahwa sikap kerja pramusaji siswa kelas XI SMKN 3 Cimahi pada mata pelajaran Tata Hidang termasuk ke dalam kategori Baik. Hal ini dapat diartikan bahwa peserta didik dapat memahami sikap kerja pramusaji pada mata pelajaran Tata Hidang, sehingga peserta didik mampu mewujudkan kompetensi yang dibutuhkan.

Tabel 2

Sikap Kerja Pramusaji pada saat Melaksanakan Preparation meliputi Mise en Place

\begin{tabular}{|c|c|c|c|}
\hline No. & $\begin{array}{c}\text { Skor } \\
\text { Aktual }\end{array}$ & $\mathbf{\%}$ & Kriteria \\
\hline 12 & 220 & 75,86 & $\begin{array}{c}\text { Sangat } \\
\text { Baik }\end{array}$ \\
\hline 13 & 194 & 66,90 & Baik \\
\hline 14 & 180 & 62,07 & Baik \\
\hline 15 & 264 & 91,03 & $\begin{array}{c}\text { Sangat } \\
\text { Baik }\end{array}$ \\
\hline $\begin{array}{c}\text { Rata } \\
\text {-rata }\end{array}$ & $\mathbf{2 1 5}$ & $\mathbf{7 4}$ & Baik \\
\hline
\end{tabular}

Berdasarkan hasil data Tabel 3 nomor 16 menunjukkan bahwa Sikap 
Kerja Pramusaji pada saat sebelum Melayani Tamu dari kemampuan seorang pramusaji harus dalam keadaan rapi, bersih, tertata, sehat jasmani dan rohani, antusias dan siap melaksanakan tugas untuk melayani tamu, rata-rata dari pernyataan nomor 16 dapat dinilai sangat baik $(97.24 \%)$.

Untuk itu sejalan dengan hasil penelitian Wowor, W (2010, hlm. 100, Vol. 1, No. 1) "Pengaruh Seragam Karyawan Terhadap Sikap Kerja Karyawan Pada Industri Perhotelan (Studi Kasus Pada Hotel XYZ Jakarta)" bahwa seragam dapat memudahkan tamu untuk mengenali karyawan saat mereka membutuhkan.

Tabel 3

Persentase Responden Data Penelitian Pada Saat Sebelum Melayani Tamu

\begin{tabular}{|c|c|c|c|}
\hline No. & $\begin{array}{c}\text { Skor } \\
\text { Aktual }\end{array}$ & $\%$ & Kriteria \\
\hline 16 & 282 & 97,24 & $\begin{array}{c}\text { Sangat } \\
\text { Baik }\end{array}$ \\
\hline $\begin{array}{c}\text { Rata } \\
\text {-rata }\end{array}$ & $\mathbf{2 8 2}$ & $\mathbf{9 7 , 2 4}$ & $\begin{array}{c}\text { Sangat } \\
\text { Baik }\end{array}$ \\
\hline
\end{tabular}

Berdasarkan hasil data Tabel 4 menunjukkan rata-rata persentase Kriteria Melaksanakan syarat sikap kerja pramusaji dalam melakukan General Service Procedure ditinjau dari kemampuan seorang pramusaji Melaksanakan standar operasional prosedur sebesar 80\%, hal ini ditafsirkan bahwa sikap kerja pramusaji siswa kelas XI SMKN 3 Cimahi pada mata pelajaran Tata Hidang termasuk ke dalam kategori Baik. Hal ini dapat diartikan bahwa peserta didik dapat memahami sikap kerja pramusaji pada mata pelajaran Tata Hidang, sehingga peserta didik mampu mewujudkan kompetensi yang dibutuhkan.

Samsuri dan Purwanto (2017, hlm. Vol. 1, No. 1) "Pengaruh Sikap Dan
Motivasi Terhadap Kinerja Karyawan Pada Mtsn Takeran Kabupaten Magetan" bahwa Secara umum dapat dikatakan bahwa kinerja merupakan ukuran keberhasilan suatu perusahaan dalam mencapai tujuan.

Tabel 4

Sikap Kerja Pramusaji pada saat Melaksanakan General Service Procedure

\begin{tabular}{|c|c|c|c|}
\hline No. & $\begin{array}{c}\text { Skor } \\
\text { Aktual }\end{array}$ & $\mathbf{\%}$ & Kriteria \\
\hline 17 & 284 & 97,93 & Sangat Baik \\
\hline 18 & 278 & 95,86 & Sangat Baik \\
\hline 19 & 278 & 95,86 & Sangat Baik \\
\hline 20 & 279 & 96,21 & Sangat Baik \\
\hline 21 & 273 & 94,14 & Sangat Baik \\
\hline 22 & 193 & 66,55 & Baik \\
\hline 23 & 83 & 28,62 & Kurang \\
\hline 24 & 274 & 94,48 & Sangat Baik \\
\hline 25 & 149 & 51,38 & Cukup \\
\hline 26 & 272 & 93,79 & Sangat Baik \\
\hline 27 & 272 & 93,79 & Sangat Baik \\
\hline 28 & 125 & 43,1 & Cukup \\
\hline 29 & 264 & 91,03 & Sangat Baik \\
\hline $\begin{array}{c}\text { Rata- } \\
\text { rata }\end{array}$ & $\mathbf{2 3 3}$ & $\mathbf{8 0}$ & Baik \\
\hline
\end{tabular}

Berdasarkan hasil data Tabel 5 menunjukkan rata-rata persentase Kriteria Melaksanakan syarat sikap kerja pramusaji pada saat pelaksanaan Restoran Tutup ditinjau dari kemampuan seorang pramusaji Melaksanakan Closing Restaurant sebesar $88 \%$, hal ini ditafsirkan bahwa sikap kerja pramusaji siswa kelas XI SMKN 3 Cimahi pada mata pelajaran Tata Hidang termasuk ke dalam kategori Sangat Baik. Hal ini dapat diartikan bahwa peserta didik dapat memahami sikap kerja pramusaji pada mata pelajaran Tata Hidang, sehingga peserta didik mampu mewujudkan kompetensi yang dibutuhkan.

Sejalan dengan hasil penelitian Subakti (2013, hlm. 597, Vol. 4, No. 2) "Pengaruh Motivasi, Kepuasan, 
Dan Sikap Kerja Terhadap Kinerja Karyawan Di Café X Bogor" bahwa Berdasarkan hal tersebut dinyatakan bahwa pengakuan terhadap manusia senantiasa mempunyai kedudukan makin penting karena masyarakat kita menuju masyarakat yang berorientasi kerja, memandang kerja sebagai satu tugas yang harus dikerjakan dengan baik.

Tabel 5

Sikap Kerja Pramusaji pada saat Melaksanakan Closing Restaurant

\begin{tabular}{|c|c|c|c|}
\hline No. & $\begin{array}{c}\text { Skor } \\
\text { Aktual }\end{array}$ & $\mathbf{\%}$ & Kriteria \\
\hline 30 & 255 & 87,93 & Sangat Baik \\
\hline 31 & 255 & 87,93 & Sangat Baik \\
\hline 32 & 263 & 90,69 & Sangat Baik \\
\hline 33 & 274 & 94,48 & Sangat Baik \\
\hline 34 & 245 & 84,48 & Sangat Baik \\
\hline 35 & 231 & 79,66 & Baik \\
\hline $\begin{array}{c}\text { Rata- } \\
\text { rata }\end{array}$ & $\mathbf{2 5 4}$ & $\mathbf{8 8}$ & Sangat Baik \\
\hline
\end{tabular}

Dapat dilihat pada Gambar 4.1 menunjukan bahwa rata-rata persentase reponden tentang Sikap Kerja Pramusaji.



Gambar 4.1

Grafik Persentase Responden tentang Sikap Kerja Pramusaji

\section{KESIMPULAN}

Berdasarkan dari hasil olah data dari penelitian Sikap Kerja Pramusaji Pada Mata Pelajaran Tata Hidang "Melayani Layanan Makanan dan Minuman" Siswa Kelas XI SMKN 3 Cimahi dapat disimpulkan bahwa:

1. Pelaksanaan sikap kerja oleh siswa kelas XI SMKN 3 Cimahi pada mata mata pelajaran Tata Hidang, berkaitan dengan syarat sikap kerja pramusaji dalam Preparation: Mise en place dan Mise en scene pada kategori baik, dengan demikian siswa dapat memahami setiap prosedur sikap kerja dan mampu mewujudkan kompetensi yang dibutuhkan.

2. Pelaksanaan sikap kerja oleh siswa kelas XI SMKN 3 Cimahi pada mata mata pelajaran Tata Hidang, berkaitan dengan syarat sikap kerja pramusaji dalam melakukan General Service Procedure pada kategori sangat baik, dengan demikian siswa dapat memahami setiap prosedur sikap kerja dan mampu mewujudkan kompetensi yang dibutuhkan.

3. Pelaksanaan sikap kerja oleh siswa kelas XI SMKN 3 Cimahi pada mata mata pelajaran Tata Hidang, berkaitan dengan syarat sikap kerja pramusaji dalam Closing Restaurant pada kategori sangat baik, dengan demikian siswa dapat memahami setiap prosedur sikap kerja dan mampu mewujudkan kompetensi yang dibutuhkan.

\section{REFERENSI}

Khoiri, Moh. 2017. Pengaruh Kualitas Kehidupan Kerja dan Sikap Kerja Terhadap Kepuasan Kerja Guru Sma Negeri Kecamatan Jekan Raya Kota Palangka Raya Provinsi Kalimantan Tengah. Tangerang: Universitas Pamulang, Vol.1, No, 5 
Maringan, dkk. 2016. Pengaruh Tingkat Pendidikan, Sikap Kerja dan Keterampilan Kerja Terhadap Prestasi Kerja Karyawan PT. Wahana Sumber Lestari. Samarinda: Universitas Mulawarman, Vol. 13

Riduwan. 2012. Belajar Mudah Penelitian. Bandung: Alfabeta

Samsuri, \& Purwanto, Hari. 2017. Pengaruh Sikap dan Motivasi Terhadap Kinerja Karyawan pada MTSN Takeran Kabupaten Magetan. Madiun: Universitas PGRI Vol. 1, No. 1

Subakti, Agung Gita. 2013. Pengaruh Motivasi, Kepuasan, Dan Sikap Kerja Terhadap Kinerja Karyawan Di Café X Bogor. Jakarta: Universitas Bina Nusantara, Vol. 4, No. 2

Wowor, Wulanmeiaya. 2010. Pengaruh Seragam Karyawan Terhadap Sikap Kerja Karyawan Pada Industri Perhotelan. Jakarta: School of Hospitality and Tourism, Vol. 1, No. 1

Yustriana, Nayundha, Elly Lasmanawati, and Yulia Rahmawati. 2016. Analisis Sikap Mahasiswa Program Studi Pendidikan Tata Boga Pada Praktik Penyelenggaraan Event Organizer Bidang Boga. Bandung: Media Pendidikan, Gizi, dan Kuliner, Vol. 5, No.1 